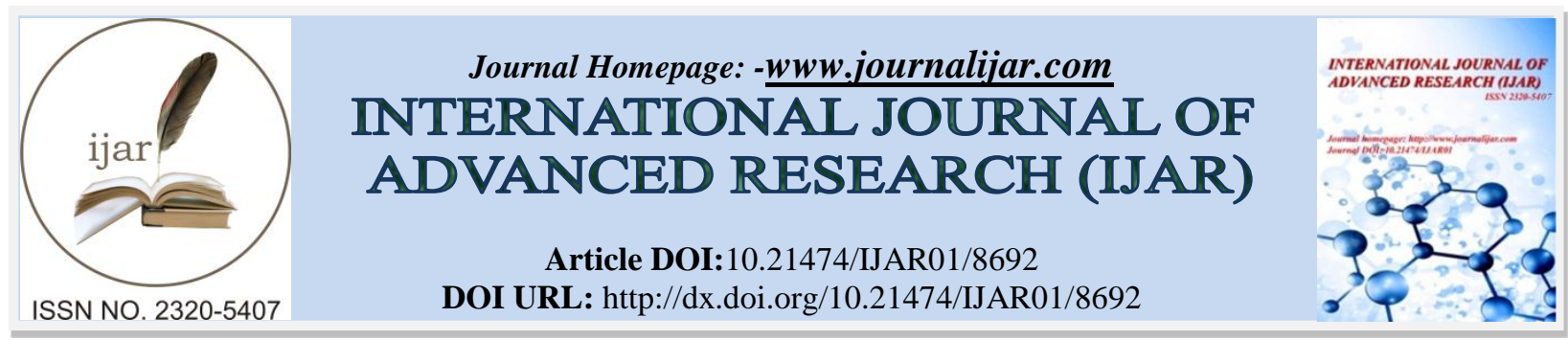

RESEARCH ARTICLE

\title{
THE ROLE OF HUMAN CAPITAL IN MAXIMIZING THE VALUE OF BUSINESSES "A CASE STUDY OF SUDANESE SHAREHOLDING COMPANIES".
}

Abubakr Abd Elbagi Mohammed Altayeb.

Associate professor in accounting - Shaqra University.

\section{Manuscript Info}

\section{Manuscript History}

Received: 14 January 2019

Final Accepted: 16 February 2019

Published: March 2019

Key words:-

Human capital, competitive,

Shareholding Companies, competition strategy.

\section{Abstract}

The study Focused on the role of Human Capital on maximizing the competitive value of the facility, in the Sudanese Shareholding Companies. The study aimed at answering the following question : What is the contribution of human capital to maximize the value of businesses? The study found that Human capital has a significant and positive impact on business companies. The study recommended that the accounting profession all over the globe should create a framework in the statement of financial position to measure the appropriate value of human resources to be attached based on the inherent qualities of human capital.

Copy Right, IJAR, 2019,. All rights reserved.

\section{Introduction:-}

Businesses look for maximizing their resources by using a competitive advantage against other competitors in the market. On this basis, many organizations claimed that the human resources apart from their competitors, as the human resources have a special value strategy; so, it is trying to find a way to attract and retain them and make continuity to the organization as competitors and their counterparts in other organizations.

The human capital contributes to make the goals through monitor and analyze the external environment, supervision of internal processes, and measure efficiency, in order to increase productivity.

\section{Statement of the Problem:}

The research intended to investigate the contribution of Human Capital in maximizing the value of the business.

\section{Hypothesis of the StudY:}

The research tests the hypothesis that human capital has a significant and positive impact on the business organization.

\section{Objective of the Study:}

The study aims at highlighting the concept of Human Capital and its importance in the development of the competitive value of the business through the presentation and analysis of its nature.

\section{Significance of the Study:}

This research is dedicated to determining The role of Human Capital in maximizing the value of the business., strengthen and reinforce the flow of cognitive abilities of individuals within the facility, which enables to produce a 
new product and then leading to activate the production marketing on one hand, and sharing maximizations strength on the other, this will earn a competitive advantage apart from the other.

\section{The Concept of Human Capital and Definitions:}

Businesses use three types of capital: physical capital (factory, stocks etc.), financial capital (investments) (Derviş Boztosun, et al, 2016: 102).

and intellectual capital

The Oxford English Dictionary defined human capital as "the skills the labor force possesses and is regarded as a resource or asset (Claudia Goldin, 2014: 2). It represents the investments made for humans and encompasses human-related factors like knowledge, skills, experience, sufficiency, and creativity. In businesses, investment in humans is the most difficult investment to control (Boztosun Aksoylu,2016: 104).

According to Okojie the human capital "abilities and skills of the human resources of a country" (Okojie, 1995). This measure builds on the basic production input of labor measure where all labors are thought to be equal .

Human capital is the stock of competencies, knowledge and personality attributes embodied in the ability to perform labor so as to produce economic value. It is the attributes gained by a worker through education and experience(www.yourarticlelibbaray.com).

OECD) defined human capital as the knowledge, skills, competencies, abilities, and attributes embodied in individuals that facilitate the creation of personal, social and economic well being (OECD,2001: 29).

Alika and Aibieyi refer to, "All the literature reviewed on the concept of human capital imply or emphasize the same thing in their various definitions, that there is a need for more investment in education and training for organizations to succeed in the contemporary world of competition. The organization that de-emphasize or lay no premium importance on the training and development of its human resource or labor force, is bound to fail or to simply put is tilting towards a state of collapse" (Alika, Aibieyi,2014: 58).

\section{The Concept of Competitive Value:}

Competitive advantage is obtained when an organization develops or acquires a set of attributes (or execution actions) that allows it to outperform its competitors(Wang, 2014).

A competitive advantage is what makes an entity's goods or services superior to all of a customer's other choices. The term is commonly used for businesses. The strategies work for any organization, country, or individual in a competitive environment(Kimberly Amadeo, 2019).

A competitive advantage is an advantage over competitors gained by offering consumers greater value, either by means of lower prices or by providing greater benefits and service that justifies higher prices(www.tutor2u.net).

Competitive advantage is revealed, when activities of a given organization are more profitable than those of its market competitors or when it outperforms them as regards other significant results of activities(Huff et al., 2009).

A superiority gained by an organization when it can provide the same value as its competitors but at a lower price, or can charge higher prices by providing greater value through differentiation. Competitive advantage results from matching core competencies to the opportunities(businessdictionary.com).

The term competitive advantage refers to the ability gained through attributes and resources to perform at a higher level than others in the same industry or market (Michael, 1985: 5).

\section{Research Methodology:-}

Inductive and deductive approach was used and the methodology of the case study. The questionnaire was adopted as a tool for collecting data to elicit the respondents perception of the human capital has a significant and positive impact on the business organization. The researcher designed the questionnaire to collect explicable data about the role of Human Capital in maximizing the value of businesses. 


\section{Distribution of Respondents:}

Out of the 60 questionnaires administered 54 were valid for final analysis .

\section{Distributions by Respondents Category:}

Distribution Respondents by age Category:

Table 4-1 shows the distribution of Respondents by Age Category. Their age distribution shows that $3(5,6 \%)$ of the respondents were below 25 years of age, $14(28,9 \%)$ between 30 - 39 years, $23(42,6 \%)$ between 40 - 49 years, 8 $(14,8 \%)$ between 50 - 59 years, while $6(11,1 \%)$ were 60 years and above. This indicates that the majority of the respondents were between the ages of $40-49$ years old.

Table 4.1:-Distribution Respondents by Age Category

\begin{tabular}{|l|l|l|}
\hline age & Frequency & Percentage \\
\hline Category & 3 & $5,6 \%$ \\
\hline Below 30 years & 14 & $28,9 \%$ \\
\hline $30-39$ years & 23 & $42,6 \%$ \\
\hline $40-49$ years & 8 & $14,8 \%$ \\
\hline $50-59$ years & 6 & $11,1 \%$ \\
\hline 60 years and above & 54 & $100 \%$ \\
\hline total &
\end{tabular}

Source: Field Survey, 2019.

Figure 4.1:-Distribution Respondents by Age Category

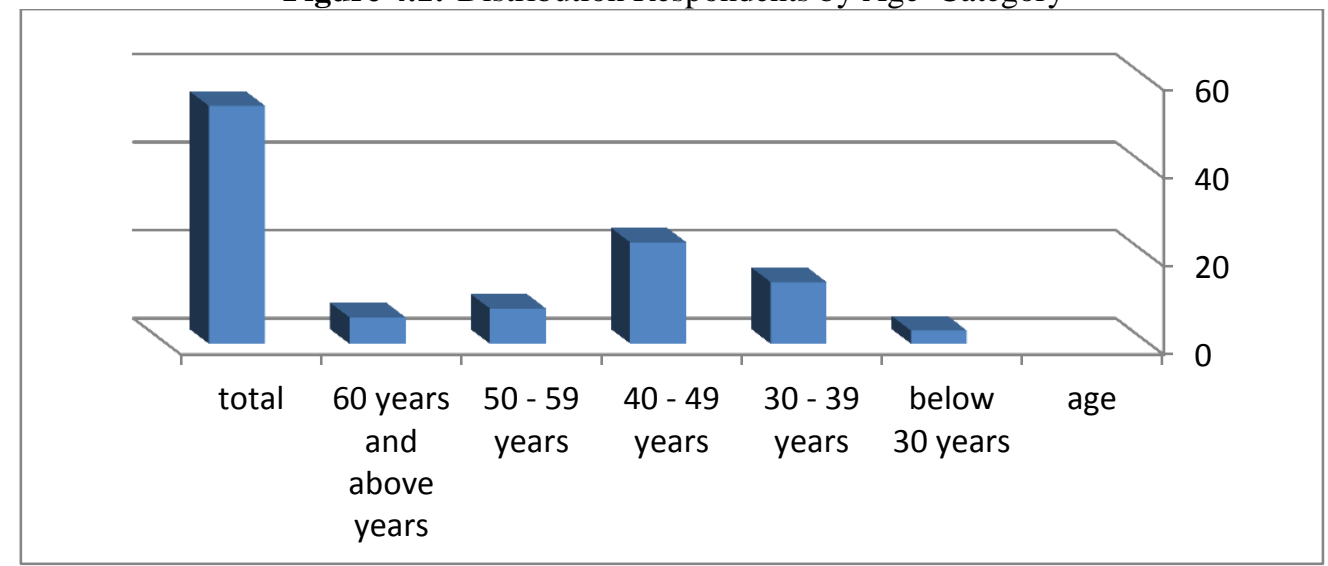

Source: Field Survey, 2019.

Distribution Respondents by qualification Category:

Table 4-2 shows the distribution of Respondents by qualification Category. The distribution of respondents by educational qualifications indicates that $3(5,6 \%)$ had DIP, $3(5,6 \%)$ had B.A, $12(22,2 \%)$ had M.A, $36(66.6 \%)$ had PH.D. This indicates that the majority of the respondents had a Ph.D. degree.

Table 4.2:-Distribution Respondents by qualification Category

\begin{tabular}{|l|l|l|}
\hline Education & frequency & percentage \\
\hline category & 3 & $5,6 \%$ \\
\hline DIP & 3 & $5,6 \%$ \\
\hline B.A & 12 & $22,2 \%$ \\
\hline M.A & 36 & $66,6 \%$ \\
\hline PH.D & 0 & 0 \\
\hline Others & 54 & $100 \%$ \\
\hline total & \multicolumn{2}{l}{$\mid$} \\
\hline
\end{tabular}

Source: Field Survey, 2019. 
Figure 4.2:-Distribution Respondents by qualification Category

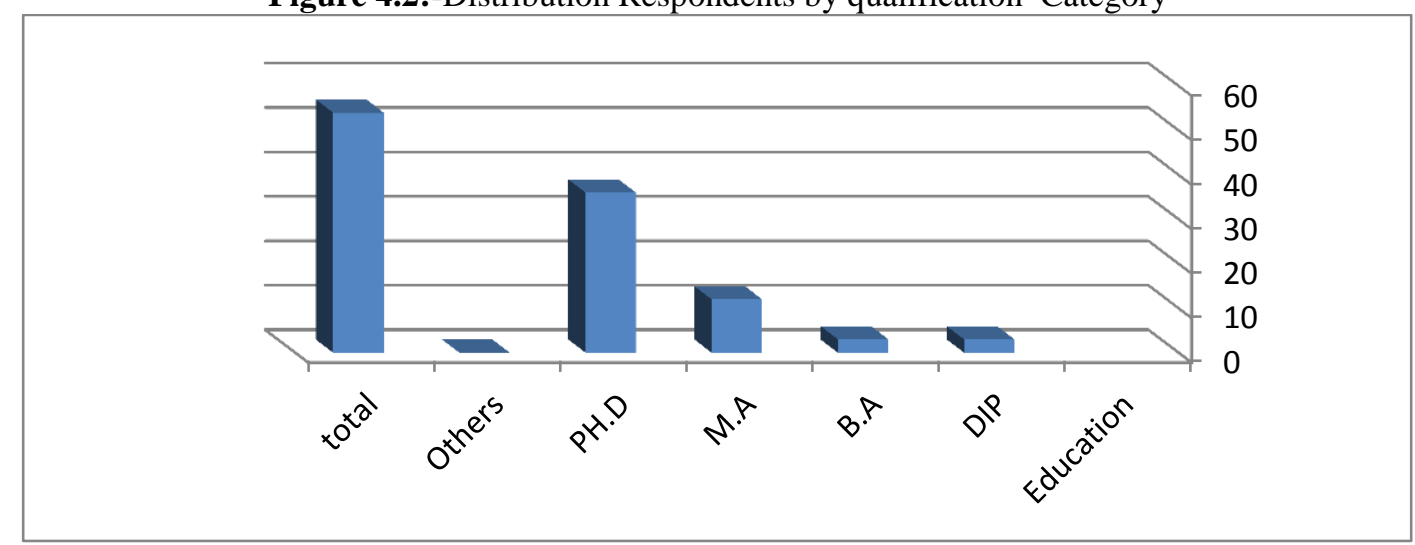

Source: Field Survey, 2019

\section{Distribution Respondents by majors Category:}

Table 4-3 shows the distribution of Respondents by majors Category. The table shows that $3(5,6 \%)$ were management, $6(11,1 \%)$ were financial management, 39(72,2\%) were accounting, while $112(35 \%)$ were other major. This indicates that the majority of the respondents were accounting majors Category.

Table 4.3:-Distribution Respondents by majors Category

\begin{tabular}{|l|l|l|}
\hline Majors & frequency & percentage \\
\hline category & 3 & $5,6 \%$ \\
\hline management & 6 & $11,1 \%$ \\
\hline financial management & 0 & 0 \\
\hline economics & 0 & 0 \\
\hline marketing & 39 & $72,2 \%$ \\
\hline accounting & 6 & $11,1 \%$ \\
\hline others & 54 & $100 \%$ \\
\hline total & & \\
\hline
\end{tabular}

Source: Field Survey, 2019

Figure 4.3:-Distribution Respondents by majors Category

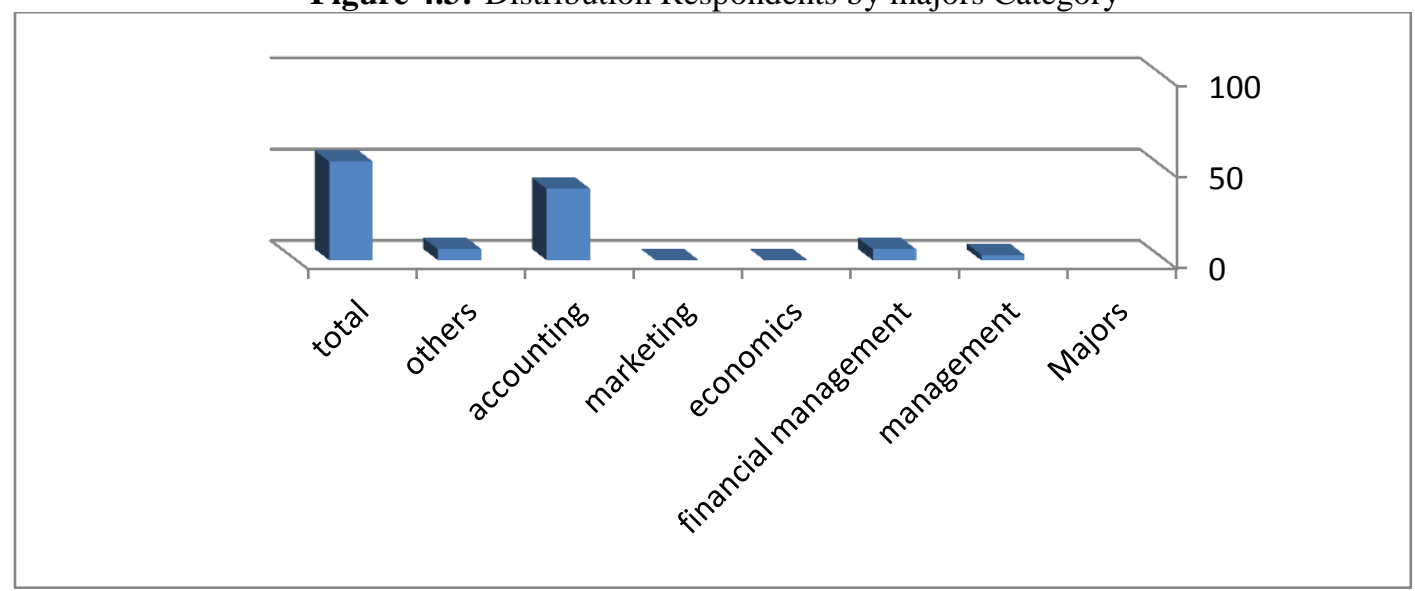

Source: Field Survey, 2019

\section{Distribution Respondents by jobs Category:}

Table 4-4 shows the distribution Respondents by jobs Category. The table shows that 21 (38,9\%) were accountant, 6 $(11,1 \%)$ were manager, $3(5,6 \%)$ were financial director, $15(27,7 \%)$ were internal audit, while $9(16,7 \%)$ were external audit. This indicates that the majority of the respondents were accountants. 
Table 4.4:-Distribution Respondents by jobs Category

\begin{tabular}{|l|l|l|}
\hline jobs & frequency & percentage \\
\hline category & 21 & $38,9 \%$ \\
\hline accountant & 6 & $11,1 \%$ \\
\hline manager & 3 & $5,6 \%$ \\
\hline financial director & 15 & $27,7 \%$ \\
\hline enternal audit & 9 & $16,7 \%$ \\
\hline external audit & 0 & 0 \\
\hline others & 54 & $100 \%$ \\
\hline total & & \\
\hline
\end{tabular}

Source: Field Survey, 2019.

Figure 4.4:-Distribution Respondents by jobs Category

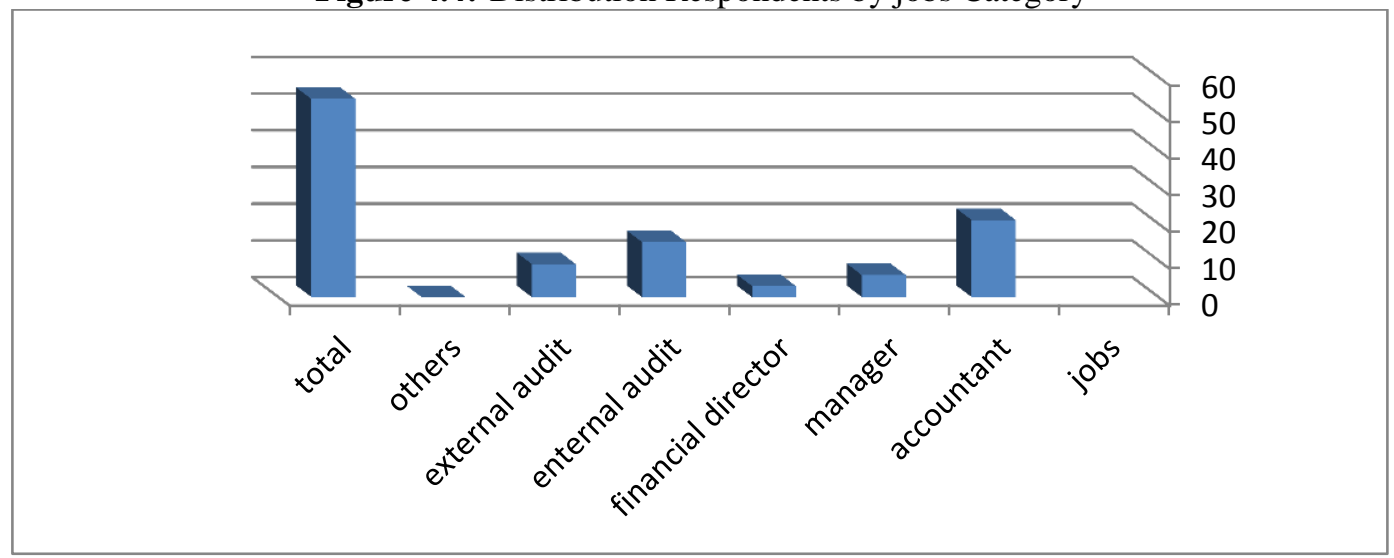

Source: Field Survey, 2019.

Distribution Respondents by Experience Category:

Table 4-5 shows the distribution Respondents by experience Category. Their experience distribution shows that 3 $(5,6 \%)$ of the respondents were below 5 years of experience, $9(16,7 \%)$ between 5 - 9 years, $15(27,8 \%)$ between 10 - 14 years, $16(29,6 \%)$ between 15 - 19 years, while $11(20,3 \%)$ were 20 years and above. This indicates that the majority of the respondents were between the experience of $10-19$ years.

Table 4.5:-Distribution Respondents by Experience Category

\begin{tabular}{|l|l|l|}
\hline Experience & frequency & percentage \\
\hline category & 3 & $5,6 \%$ \\
\hline below 5 years & 9 & $16,7 \%$ \\
\hline $5-9$ years & 15 & $27,8 \%$ \\
\hline $10-14$ years & 16 & 29,6 \\
\hline $15-19$ years & 11 & $20,3 \%$ \\
\hline 20 years and above & 54 & \\
\hline total & 54 & \\
\hline
\end{tabular}

Source: Field Survey, 2019. 
Figure 4.5:-Distribution Respondents by Experience Category

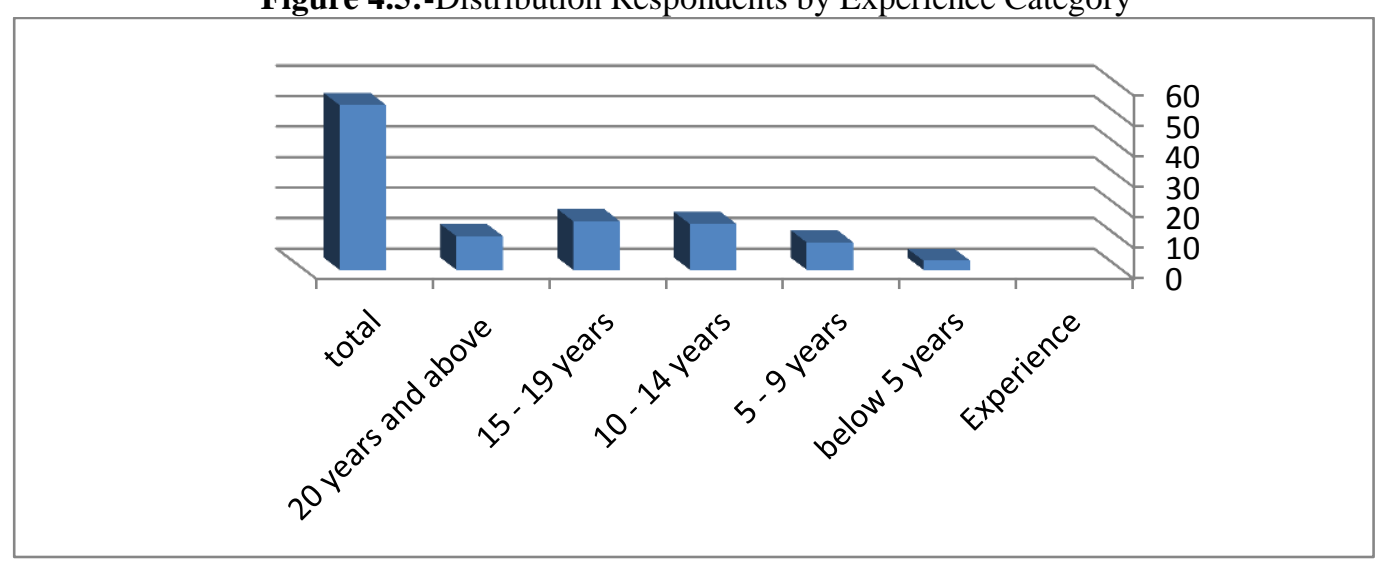

Source: Field Survey, 2019.

\section{Measurement of Variable:}

The hypothesis for this study is operationalized using Correlation Coefficient:

That human capital has a significant and positive impact on the business organization.

Table 4-6 shows the Respondents' opinions about Human capital is vital to the development of business profitability. Their Respondents' opinions show that $51(94,4 \%)$ of the respondents agreed, $3(5,6 \%)$ neutral. This indicates that the majority of the respondents agreed that Human capital is vital to the development of business profitability.

Table 4.6:-Respondents' opinions about:

Human capital is vital to the development of the business profitability

\begin{tabular}{|l|l|l|}
\hline & Frequency & Percentage \\
\hline Agree & 51 & $94,4 \%$ \\
\hline Neutral & 3 & $5,6 \%$ \\
\hline Disagree & 0 & 0 \\
\hline Total & 54 & $100 \%$ \\
\hline
\end{tabular}

Source: Field Survey, 2019.

Figure 4.6:- Respondents' opinions about Human capital is vital to the development of the business profitability

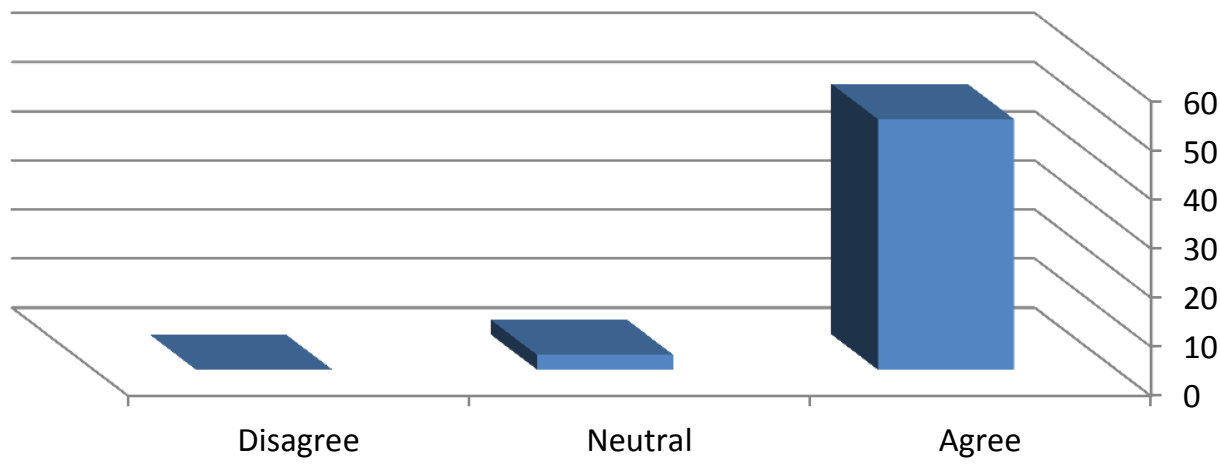

Source: Field Survey, 2019.

Table 4-7 shows the Respondents' opinions about Human capital management is the major determinant of business performance. Their Respondents' opinions show that $45(83,3 \%)$ of the respondents agreed, $9(16,7 \% \%)$ neutral. This indicates that the majority of the respondents confirmed that the Human capital management is the major determinant of the business performance. 
Table 4.7:- Respondents' opinions about:Human capital management is the major determinant of the business performance

\begin{tabular}{|l|l|l|}
\hline & Frequency & Percentage \\
\hline Agree & 45 & $83,3 \%$ \\
\hline Neutral & 9 & $16,7 \%$ \\
\hline Disagree & 0 & 0 \\
\hline Total & 54 & $100 \%$ \\
\hline
\end{tabular}

Source: Field Survey, 2019.

Figure 4.7: -Respondents' opinions about Human capital management is the major determinant of the business performance

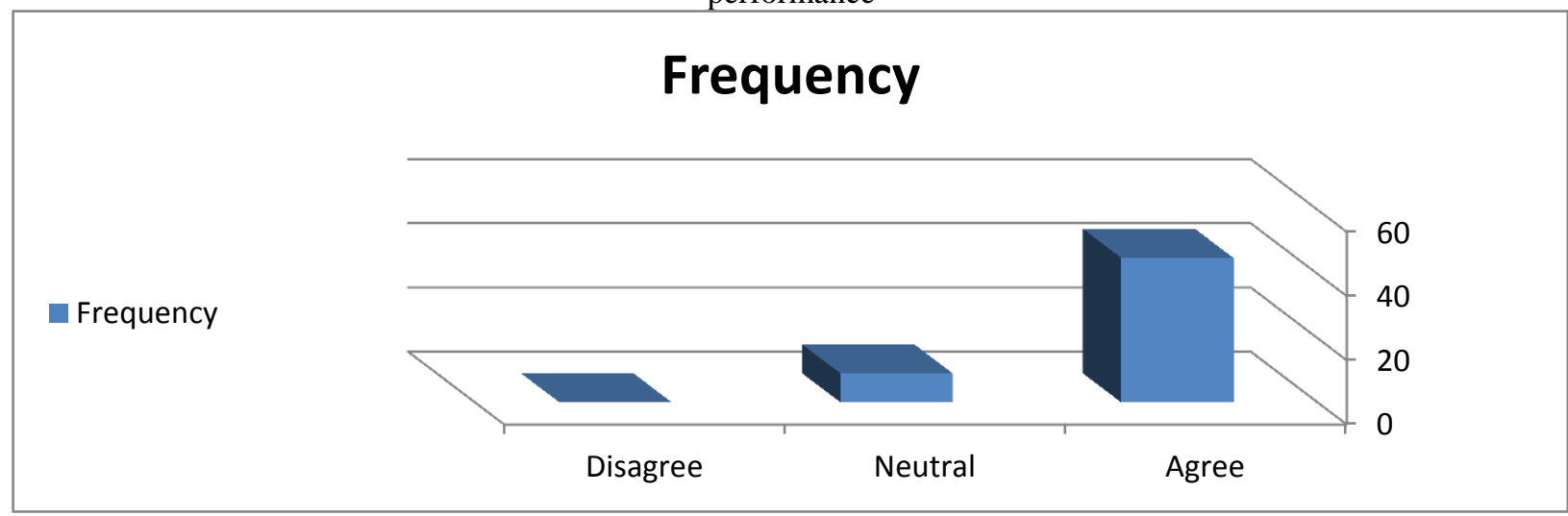

Source: Field Survey, 2019.

Table 4-8 shows the Respondents' opinions about human capital should be capitalized and treated as assets in the business. Their Respondents' opinions show that all of the respondents were agreed. This indicates that all of the respondents agreed that human capital should be capitalized and treated as assets in the business.

Table 4.8:- Respondents' opinions about:Human capital should be capitalized and treated as assets in business

\begin{tabular}{|l|l|l|}
\hline & Frequency & Percentage \\
\hline Agree & 54 & $100 \%$ \\
\hline Neutral & 0 & 0 \\
\hline Disagree & 0 & 0 \\
\hline Total & 54 & $100 \%$ \\
\hline
\end{tabular}

Source: Field Survey, 2019.

Figure 4.8:- Respondents' opinions about Human capital should be capitalized and treated as assets in business

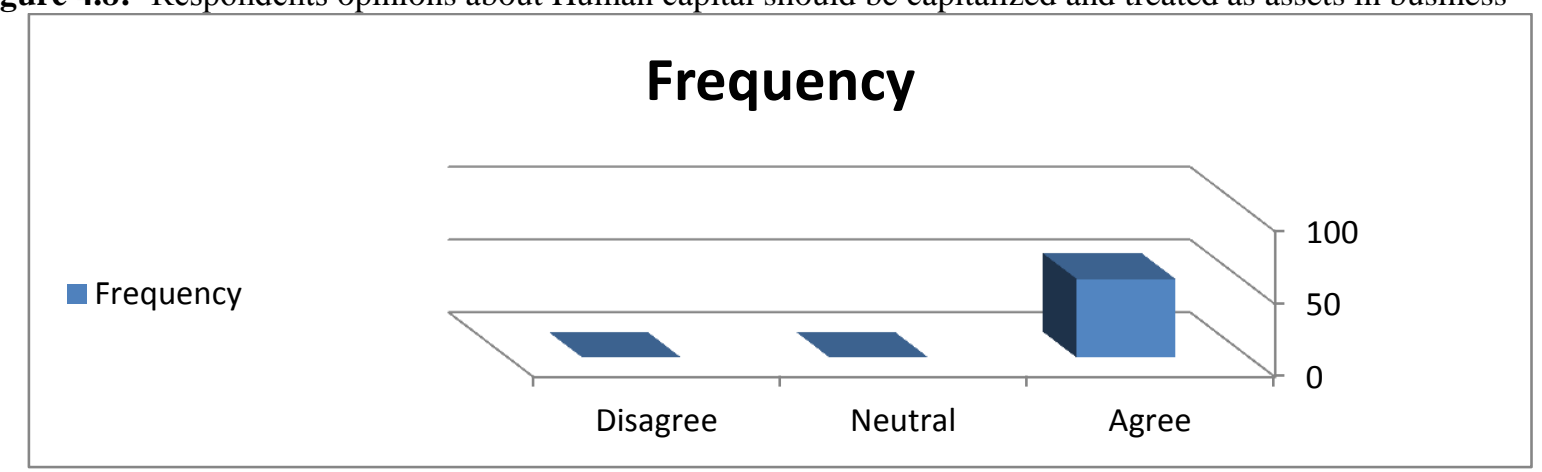

Source: Field Survey, 2019.

Table 4-9 shows the Respondents' opinions about the current organizations are regarded as human capital as an important element in performance and maximizing competitive value. Their Respondents' opinions show that 24 $(44,4 \%)$ of the respondents agreed, $24(44,4 \%)$ of the respondents were neutral, while $6(11,1 \%)$ of the respondents 
disagreed. This indicates that no dealt for the current organizations is regarding human capital as an important element in performance and maximizing competitive value.

Table 4.9:-Respondents' opinions about:The current organizations is regard human capital as important element in performance and maximizing competitive value.

\begin{tabular}{|l|l|l|}
\hline & Frequency & Percentage \\
\hline Agree & 24 & $44,4 \%$ \\
\hline Neutral & 24 & $44,4 \%$ \\
\hline Disagree & 6 & $11,1 \%$ \\
\hline Total & 54 & $100 \%$ \\
\hline
\end{tabular}

Source: Field Survey, 2019.

Figure 4.9: -Respondents' opinions about The current organizations is regard human capital as an important element in performance and maximizing competitive value.

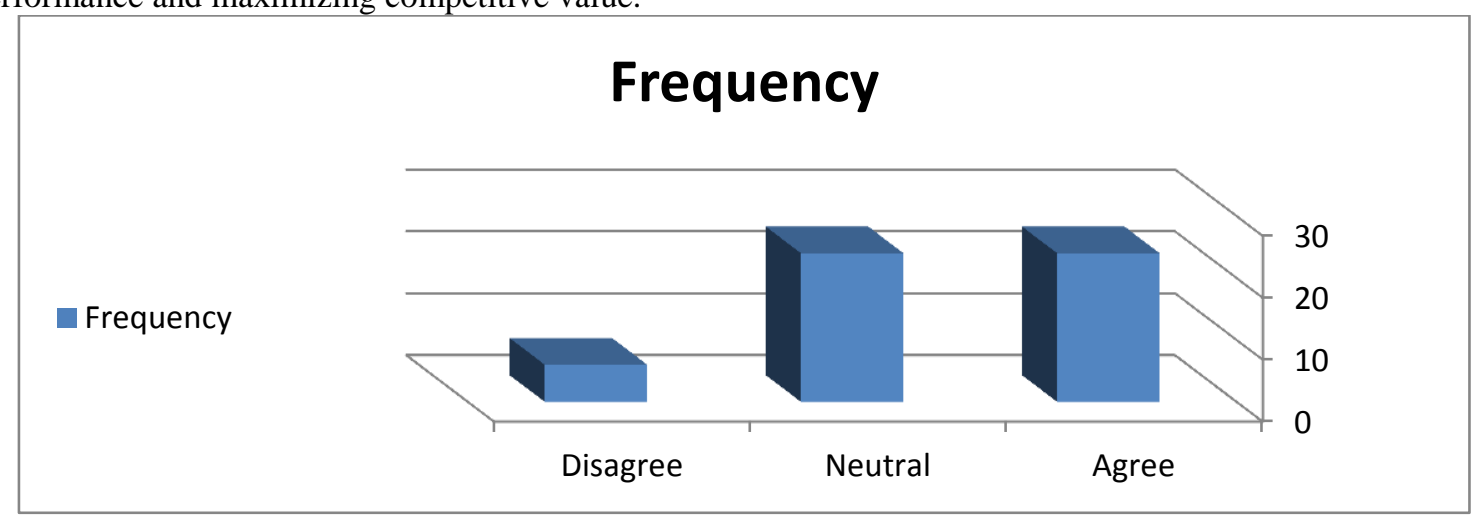

Source: Field Survey, 2019.

Table 4-10 shows the Respondents' opinions about the successes of business is mostly due to its human capital management. Their Respondents' opinions show that $33(61,1 \%)$ of the respondents agreed, $21(38,9 \%)$ of the respondents were neutral. This indicates that the majority of the respondents confirmed that the successes of business are mostly due to its human capital management.

Table 4.10: -Respondents' opinions about: successes of business is mostly due to its human capital management

\begin{tabular}{|l|l|l|}
\hline & Frequency & Percentage \\
\hline Agree & 33 & $61,1 \%$ \\
\hline Neutral & 21 & $38,9 \%$ \\
\hline Disagree & 0 & 0 \\
\hline Total & 54 & $100 \%$ \\
\hline
\end{tabular}

Source: Field Survey, 2019.

Figure 4.10: -Respondents' opinions about successes of business is mostly due to its human capital management

\section{Frequency}

Frequency

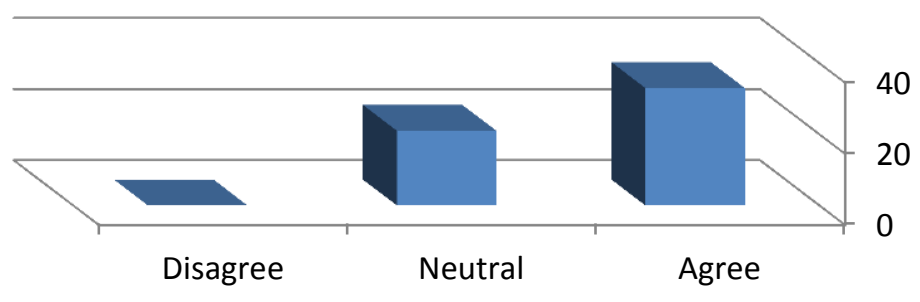

Source: Field Survey, 2019. 
Table 4-11 shows the Respondents' opinions about the human capital in business should be given special consideration when determining its performance, not just other assets. Their Respondents' opinions show that 36 $(66,7 \%)$ of the respondents agreed, $18(33,3 \%)$ of the respondents were neutral. This indicates that the majority of the respondents confirmed that the human capital in business should be given special consideration when determining its performance, not just other assets.

Table 4.11:- Respondents' opinions about: Human capital in business should be given special consideration when determining its performance not just other assets.

\begin{tabular}{|l|l|l|}
\hline & Frequency & Percentage \\
\hline Agree & 36 & 66,7 \\
\hline Neutral & 21 & $33,3 \%$ \\
\hline Disagree & 0 & 0 \\
\hline Total & 54 & $100 \%$ \\
\hline
\end{tabular}

Source: Field Survey, 2019.

Figure 4.11:- Respondents' opinions about Human capital in business should be given special consideration when determining its performance not just other assets.

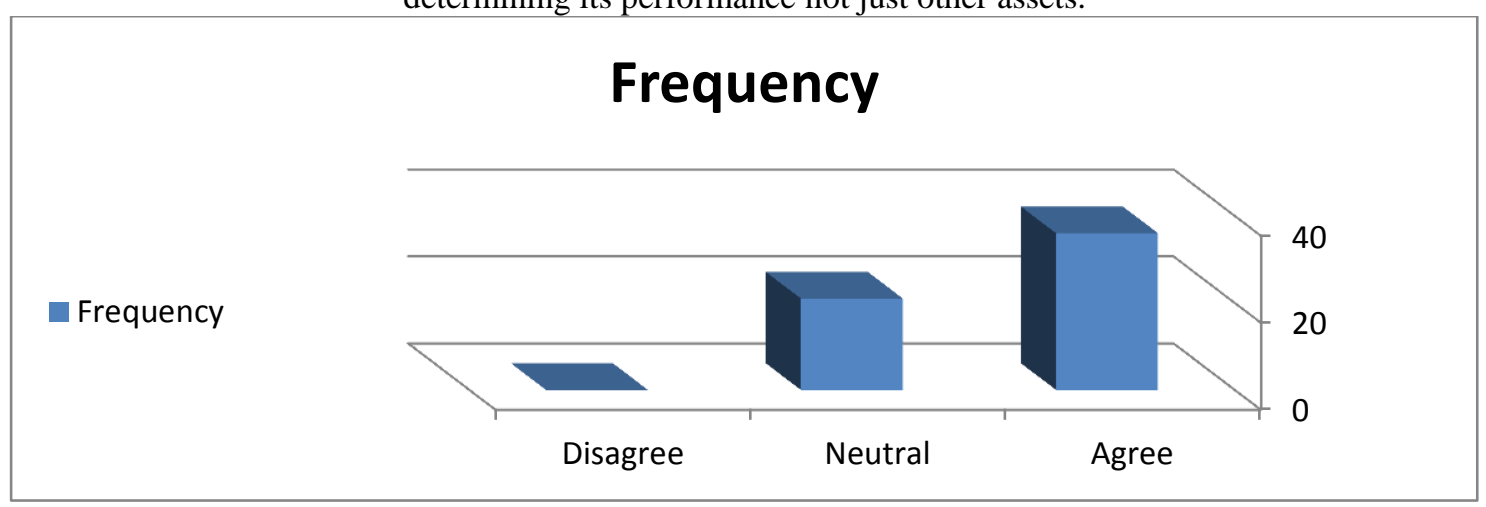

Source: Field Survey, 2019.

Table 4-12 shows the Respondents' opinions about human capital provide competitive value faster as other business performance. Their Respondents' opinions show that $51(94,4 \%)$ of the respondents agreed, 3 (5,6\%) of the respondents were neutral. This indicates that the majority of the respondents agreed that human capital provides competitive value faster as other business performance.

Table 4.12:- Respondents' opinions about: Human capital provide competitive value faster as other business performance.

\begin{tabular}{|l|l|l|}
\hline & Frequency & Percentage \\
\hline Agree & 51 & $94,4 \%$ \\
\hline Neutral & 3 & $5,6 \%$ \\
\hline Disagree & 0 & 0 \\
\hline Total & 54 & $100 \%$ \\
\hline
\end{tabular}

Source: Field Survey, 2019.

Figure 4.12:- Respondents' opinions about Human capital provide competitive value faster as other business performance .

Frequency

Source: Field Survey, 2019. 
Table 4-13 shows the Respond Respondents'ents opinions about Human capital is to improve the business's performance and should enhance the competitive value. The Respondents' opinions showed that $39(72,2 \%)$ of the respondents agreed, $12(22,2 \%)$ of the respondents were neutral, while $3(5,6 \%)$ of the respondents disagreed. This indicates that the majority of the respondents agreed that Human capital improves the business's performance and should enhance the competitive value.

Table 4.13:- Respondents' opinions about:Human capital is improve the business performance and should be enhanced the competitive value

\begin{tabular}{|l|l|l|}
\hline & Frequency & Percentage \\
\hline Agree & 39 & $72,2 \%$ \\
\hline Neutral & 12 & $22,2 \%$ \\
\hline Disagree & 3 & $5,6 \%$ \\
\hline Total & 54 & $100 \%$ \\
\hline
\end{tabular}

Source: Field Survey, 2019.

Figure 4.13:- Respondents' opinions about Human capital is improve the business performance and should be enhances the competitive value

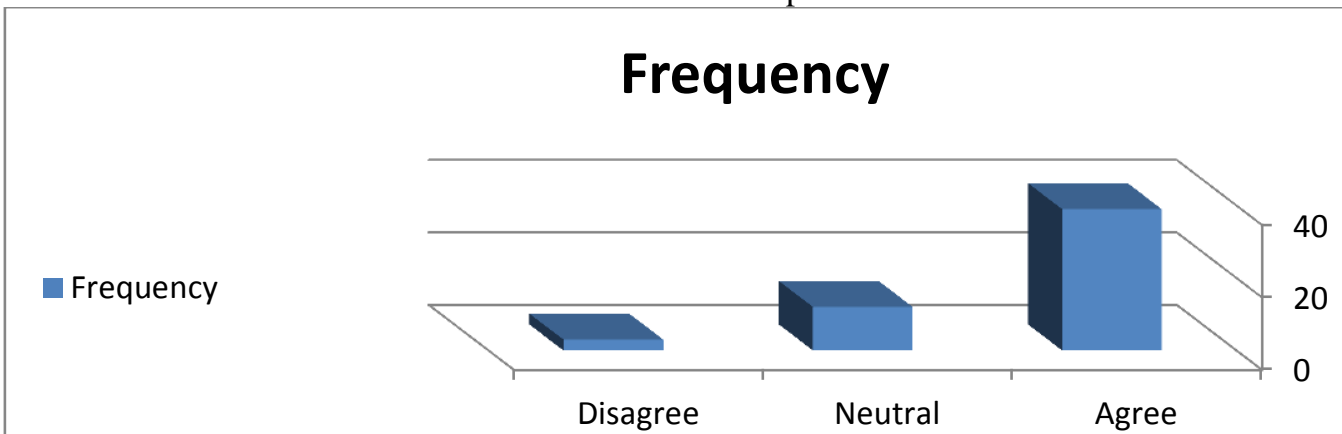

Source: Field Survey, 2019.

Table 4-14 shows the Respondents' opinions about human capital is helpful to the growth and development of business organizations. The Respondents' opinions showed that 45 (83,3\%) of the respondents agreed, $9(16,7 \%)$ of the respondents were neutral. This indicates that the majority of the respondents agreed that human capital is helpful to the growth and development of business organizations.

Table 4.14:- Respondents' opinions about:Human capital is helpful to the growth and development of business organizations.

\begin{tabular}{|l|l|l|}
\hline & Frequency & Percentage \\
\hline Agree & 45 & $83,3 \%$ \\
\hline Neutral & 9 & $16,7 \%$ \\
\hline Disagree & 0 & 0 \\
\hline Total & 54 & $100 \%$ \\
\hline
\end{tabular}

Source: Field Survey, 2019. 
Figure 4.14:-Respondents opinions aboutHuman capital is helpful to the growth and development of business organizations.

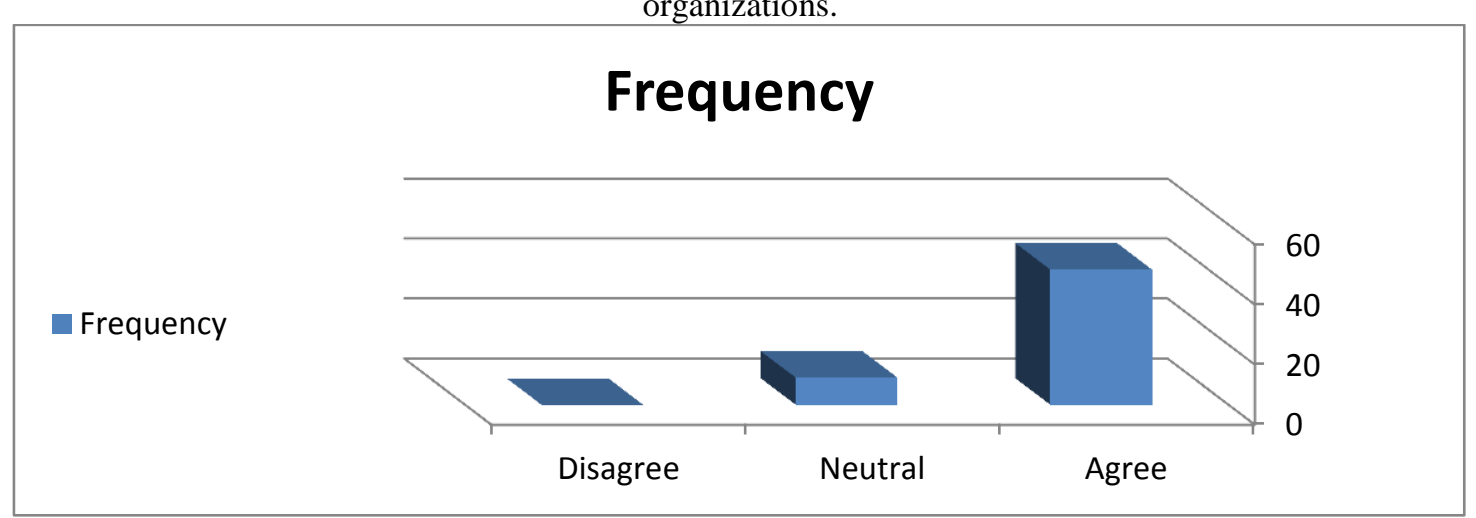

Source: Field Survey, 2019.

Table 4-15 shows the Respondents' opinions about business organizations should provide adequate information about human capital performance and profitability. The Respondents' opinions showed that $45(83,3 \%)$ of the respondents agreed, $6(11,1 \%)$ of the Respondents' disagreed, while $3(5,6 \%)$ of the respondents were neutral. This indicates that the majority of the respondents agreed that business organizations should provide adequate information about human capital performance and profitability.

Table 4.15:- Respondents' opinions about:The business organizations should provide adequate information about the human capital performance and profitability competitive value

\begin{tabular}{|l|l|l|}
\hline & Frequency & Percentage \\
\hline Agree & 45 & $83,3 \%$ \\
\hline Neutral & 3 & $5,6 \%$ \\
\hline Disagree & 6 & $11,1 \%$ \\
\hline Total & 54 & $100 \%$ \\
\hline
\end{tabular}

Source: Field Survey, 2019.

Figure 4.15:- Respondents' opinions about The business organizations should provide adequate information about the human capital performance and profitability

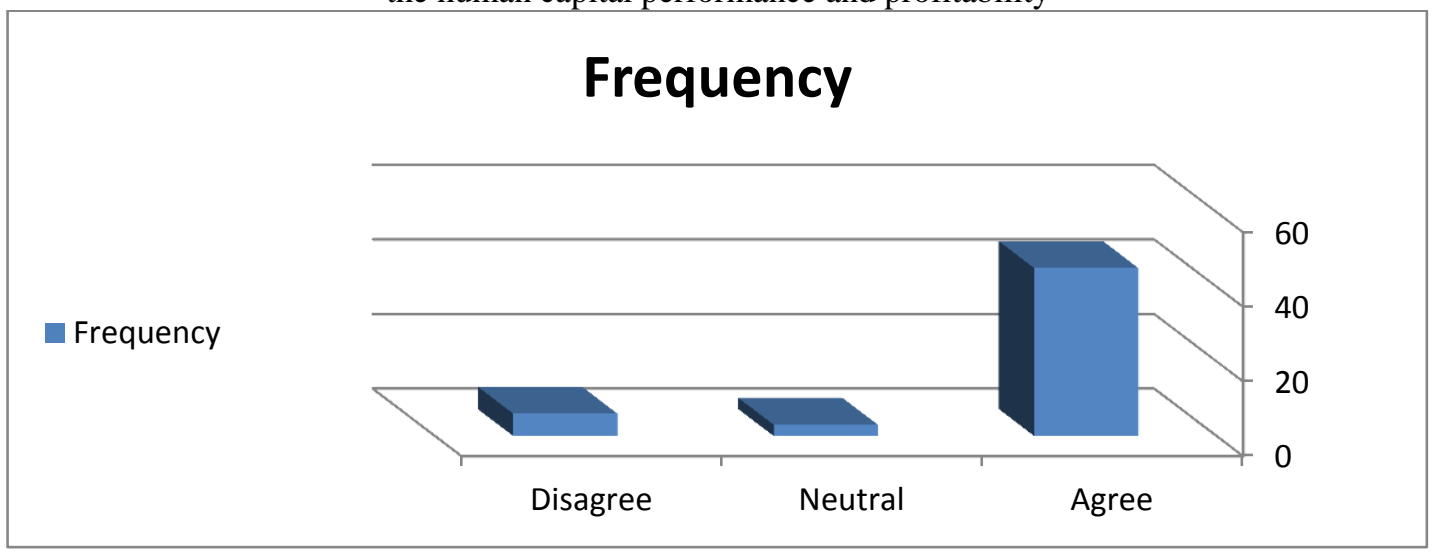

Source: Field Survey, 2019.

The results presented in table 3-6 to table 3-15 indicate that "Human capital development value has a significant and positive impact on the business companies". 


\section{Conclusion:-}

After reviewing theoretical and practical Studies of Human Capital and its role in maximizing the value of competition, the following results are obtained:

1. The study has shown that Human capital has a significant and positive impact on the business company.

2. The study revealed that the majority of respondents $(42,6 \%)$ were between the age of $40-49$ years old, and a majority $(66,6 \%)$ had a Ph.D. degree, The majority $(38,9 \%)$ was an accountant, The majority $(57,4)$ was between the experience of $10-19$ years.

3. The study revealed that $94,4 \%$ confirmed Human capital is vital to the development of the business profitability. It was also revealed that $83,3 \%$ Human capital management is the major determinant of the business performance. $100 \%$ of the respondents agreed that human capital should be capitalized and treated as assets in a business.

4. The study also shows $94,4 \%$ agreed that human capital provides competitive value faster as other business performance. While $44,4 \%$ respondents agreed that the current organizations are regarded as human capital as an important element in performance and maximizing competitive value.

\section{The most important recommendations:}

1. The studies recommended that The accounting profession all over the globe should create a framework in the statement of financial position to measuring the appropriate value of human resources to be attached based on the inherent qualities of human capital.

2. The Company should strengthen the role of Human Capital in achieving competitive advantage.

3. Identifying the factors that limit the role of Human Capital in achieving the company's competitive advantage and develop appropriate solutions.

4. An appropriate environment should be initialized to enhance the role of Human Capital in achieving the company's competitive advantage.

\section{References:-}

1. Alika, Iyere Joseph, Stan Aibieyi, (2014), Human Capital: Definitions, Approaches and Management Dynamics, Journal of Business Administration and Education, Volume 5, Number1.

2. Bontis, N, et al, (1999) The Knowledge Toolbox: A Review of Tools Available to Measure and Manage Intangible Resources, European Management Journal, 17 (4).

3. Chacarbaghi, Lynch (1999), Competitive Advantage: Creating and Sustaining Superior Performance by Michael E. Porter.

4. Claudia Goldin, (2014), Human Capital, Handbook of Cliometrics, Claude Diebolt, and Michael Haupert, editors Springer-Verlag, forthcoming.

5. Derviş Boztosun, et al,( 2016) The Role of Human Capital in Economic Growth, Economics World, May-June, Vol. 4, No. 3.

6. Huff, A. S., Floyd, S. W., Sherman, H. D., Terjesen, S. (2009), Strategic Management. Logic and Action, John Wiley $\&$ Sons, New York.

7. Kimberly Amadeo, (2019), what is the competitive advantage, www.thebalance.com.

8. Lucas, R. E. (1988). On the mechanics of economic development. Journal of Monetary Economics, 22.

9. OECD,(2001), The Value Of People, OECD Insights: Human Capital, https://www.oecd.org/insights.

10. Okojie, C.E.E. (1995) "Human Capital Formation for Productivity Growth in Nigeria" in The Nigerian Economic and Financial Review Vol. 1, No.1.

11. Porter, Michael E. (1985). Competitive Advantage. Free Press. ISBN 978-0-684-84146-5.

12. Wang, H.-L. (2014), "Theories for competitive advantage", Being Practical with Theory: A Window into Business Research, Wollongong, Australia: Theory, Australia.

13. http://www.investorwords.com/2359/human_capital.html.

14. http://www.yourarticlelibrary.com/economics/human-capital-concept-and-significance-of-human-capital/40431.

15. https://www.economicshelp.org/blog/26076/economics/human-capital-definition-and-importance/

16. https://en.wikipedia.org/wiki/Human_capital

17. https://en.wikipedia.org/wiki/Competitive_advantage.

18. www.referenceforbusiness.com, (2016)."Generic Competitive Strategies - strategy, levels, system, advantages, school, company, business, the system".www.referenceforbusiness.com, (2016)."Generic Competitive Strategies strategy, levels, system, advantages, school, company, business, the system".

19. http://www.businessdictionary.com/definition/competitive-advantage.html.

20. https://www.tutor2u.net/business/reference/competitive-advantage 